\section{Reproductive rights of women: reflecting attitudes and practices in a public hospital}

Ana Izabel Lopes Cunha', Carla Lidiane Jácome de Lima², Patrícia Simplício de Oliveira Lima², Eliane Cristina da Silva², Marta Miriam Lopes Costa²

1 Integrated Residency in Multiprofessional Care Hospital, Federal University of Paraíba, Paraíba, PB, Brazil. Corresponding author.

2 The Graduate Program in Nursing, Federal University of Paraíba, Paraíba, PB, Brazil.

The disregard and disrespect for sexual and reproductive rights allow for the imposition of norms and derogatory values by some health professionals. In view of this, the objective of this study was to investigate the perception of health professionals involved in care for women about the reproductive rights of women during the antepartum, childbirth and the puerperium in a Public Maternity Hospital of João Pessoa - PB. A descriptive study of qualitative approach performed with 42 professionals from a public maternity hospital. The content analysis resulted in two categories, the first with three subcategories and the second with two subcategories. Through this study showed that women are more exposed to the model of technocratic assistance, which reinforces the loss of their role during the whole perinatal stage, being therefore necessary actions more effective for quality assistance and humanization.

\section{Contact information:}

\section{Ana Izabel Lopes Cunha.}

$\risingdotseq$ anaizabelcunha@hotmail.com

Keywords

Women's Health; Reproductive Rights; Humanization of Assistance; Perinatal Care.

\section{Introduction}

From the $20^{\text {th }}$ century, care to women during the period of maternity has gone through major changes, leaving to be home and natural to be hospital and surgical. In addition, there was the belief of pregnancy and birth to be pathological processes that needed medications and monitoring, what increased medical interventions, mainly in North America [1-2].

In Brazil, the process of institutionalization of childbirth began during the 1940s and represented the first public health action turned to women. Until the early 1960s, the concern with maternal health was restricted to childbirth services [3].

All of these changes gave more and more space to technology, reducing the contact between the professional and the woman, making the experience of childbirth a mechanical procedure, without the use of biopsychosocial aspects that involve this time [4].

Considering the increasing dehumanization of care provided to women during pregnancy, child- 
birth and the puerperium, the Ministry of Health, through the decree 569 from 2000, instituted the Program of Humanization of Prenatal and Birth PHNP of SUS as the first initiative to ensure the right to assisted childbirth and puerperium so humanized and safe [3.5].

From this perspective, it is considered a humanized childbirth the one which the woman is empowered, with the control of decisions about everything that involves the moment of childbirth, mainly, the choice of a companion during parturition procedure, childbirth and postpartum, which is guaranteed by Law N 11,108, dated $7^{\text {th }}$ of April, 2005 [2.6]. Therefore, the humanized care provided in childbirth is an essential condition to promote respect, acceptance and improvement in quality of life of the mother and neonatal of quality [7].

Currently, although there are regulated policies that aim to ensure attention worthy and humanized care, many times, women do not have their rights respected, these being constantly threatened [8].

The disregard and disrespect for sexual and reproductive rights, enabling the imposition of norms and values by calling some health professionals [9]. The non-guaranteed rights and the implementation of overcome scientifically practices that injure the physical and psychological integrity of women and their babies, constitutes obstetrical and institutional violence.

A study conducted in hospitals in São Paulo has identified that the possible causes for the institutional violence in maternity wards are the trivialization of violence in vocational training, work bound associated with lack of resources, lack of supervision and punishment against abuse on the part of the institution, social discrimination toward the patients and, finally, the resistance to changes in professional attitudes and the adoption of procedures [10].

In this way, it becomes clear that in the current scenario of health the bodily integrity of women and their emotional well-being do not seem to be relevant outcome for many public health professionals, because there are few invested about satisfac- tion with the experience of giving birth [10].

The interest in the issue arose from the experience of the author as scholarship holder of the Educational Program for Health Work (PET-health), developing educational activities in the sectors of a maternity ward in the city of João Pessoa, on which occasion it was observed the violation of women's rights by the professionals. Raising the question: What is the perception of health professionals about the reproductive rights of women, involved in care for women during the antepartum, childbirth and the puerperium?

Before the above, the study presents as objectives: to determine the perception of health professionals about the reproductive rights of women, involved in attention to the woman during the prepartum, childbirth and the puerperium in a Public Maternity de João Pessoa-PB.

\section{Method}

This is considered a descriptive study of a qualitative approach; conducted with professionals working in a public maternity hospital of João Pessoa, PB, in the period from November 2013 to February 2014. The maternity ward was chosen for being a reference in care to women in high-risk pregnancy, and/or in a situation of sexual and domestic violence. The same is also a state reference to attention to the Kangaroo Mother Method and scenario of practice of the Educational Program for the Work of the Ministry of Health - PROPET NETWORKS.

The study population consisted of 465 professionals working in the services of prepartum, childbirth and the puerperium, among which, met social workers, nurses, physiotherapists, porters, physicians, nutritionists, psychologists, receptionists and nurses. For the selection of the sample, the inclusion criteria were: working in the services of pre-birth, childbirth and the puerperium in the period of collection and accepting the invitation to participate in the workshop entitled "Third Meeting of the 
Worker", with the theme "Reproductive Rights of Women: Reflecting Attitudes and Practices".

Initially, the professionals were invited to participate in the workshop through formal invitations, and posters attached on the notice boards of each sector. The event was held in the integration of professional continuing education service with the researchers from PROPET NETWORKS. The workshop was organized in two cycles of three days each, totaling six meetings, which took place in the Auditorium of the institution itself in shifts in the morning, afternoon and evening in order to achieve a significant sample and cover the widest possible number of workers.

These meetings consisted initially in the application of a structured questionnaire with the following question: "In your opinion, do you think that women should have the right to choose their type of birth? Why?" followed by the presentation of videos, exposure of educational materials and, finally, to group discussions. The inquiry was made in the questionnaire had as main objective to provoke reflection about the autonomy and participation of women at the time of childbirth, bearing in mind that these concepts go far beyond the idea of giving "right to the woman to choose", but also for issues related to the reception, clarification, active participation and trust.

Participated in the workshop 109 professionals, of which only 74 met the inclusion criteria. However, the sample was composed of 42 professionals, since this was the amount of volunteers who agreed to participate in the study. It should be emphasized that the study was approved by the Research Ethics Committee of the Center for Science and Health of the Federal University of Paraíba - CEP/CCS/UFPB under protocol 0713/13, CAAE: 18235613.6.0000.5188, and all of the volunteers were instructed about the study and signed an Informed Consent Form, agreeing to their participation in the same, being in accordance with the Resolution 466/12 of the National Health Council.
The answers from the questions were typed in full by the researcher. To maintain the confidentiality of participants, the responses from the questionnaires were identified through words that symbolize each sector of the institution (Sorting- welcome, prepartum- state, Rooming- company, Kangaroo- hug, UCIN- affection, NICU- careful, Bank of Milk- attention, Psychology- listening, Social Service- smile), combined with a number that represents the number of participants in each professional category (Nurse 1 to 13, Physiotherapist 14 to 19, doctor, 20 to 21 , social worker 22 to 24 , Psychology 25 to 27 , nursing technicians 28 to 42), for example: Smile1.

The analysis was made by means of the technique of content analysis, following the steps proposed by Bardin: pre-analysis, coding, inference and interpretation of data [11]. Thus the corpus or the central idea of the matter in focus was formed by the answers produced by professionals in the context of the questionnaire. The corpus of work was held the stage of its decomposition into smaller units or constituent elements, also called "units of analysis", which were grouped from common or approximate characteristics. The unit of analysis chosen for this study was the theme that is included in the area of semantics and is intended to study the meaning of the words, thus generating thematic categories.

\section{Results}

The study included 42 professionals, two of whom were physicians, three psychologists, three social workers, six physical therapists, 13 nurses and 15 nursing technicians. It was obtained representation of the following sectors: screening (1), pre-childbirth (5), housing assembly (9), kangaroo, (8), UCIN (3), the NICU (5), bank of milk (6), Psychology (3) and Social Services (3).

From the analysis of the empirical material, two categories emerged; the first with three sub-categories and the second with two subcategories, thus described: Category 1- Agreement in relation to the 
choice of birth type, category 1- Humanization of childbirth, sub 2- Autonomy of pregnant women, and subcategory 3- decision together. Category 2- dissent in relation to the choice of birth type, category 1- Lack of women and sub-category 2Evaluation and medical indication.

\section{Category 1 - Agreement in relation to the choice of birth type \\ Sub-category 1- Humanization of childbirth}

With respect to the discourse of some professionals in this study, it was possible to realize that their prospects with regard to the right of choice of patients were related to the humanization in the broadest sense, addressing other concepts, like acceptance, clarification, creation of bond and security.

Yes, this is humanization. (Companion 1)

Yes, there are the psychological stresses that can affect the time of childbirth. The patient received is easier to work and clarify the types of childbirth. (Hug 2)

Yes. Of course, this choice should be after the clarification of the methods and disadvantages of types of childbirth. Summarizing it should be clarified. (Hosting 14)

Yes, because she would choose what would be best for her and the newborn. Excellent choice for strengthening the emotional bond. (Hearing 25)

Yes, women would feel safer in their choice and made sure they would not afraid to have the baby. (Companion 28)

Yes, she would feel more comfortable. (Companion 29)

\section{Subcategory 2- The pregnants autonomy}

The report expresses to the professional that the woman has the right to choose how to be her childbirth, respecting her complaints, expectations and desires.

Yes, a way to feel confident is the autonomy in its power to give birth. (Hearing 2)

Yes, after all, the woman's will must prevail, childbirth is it. (Affection 3)

Yes, the fact that it is master of its body. (Hosting 15)

Yes, it is a unique moment in which the same should have full freedom of choice, not forgetting that the drive offers conditions to these births. (Hosting 4)

Yes, because birth is a special time where she can choose the type that allow safe and make us feel good. (Hug 29)

Yes, she has her beliefs, culture, experiences and the right to choose makes the birth smooth and less traumatic. (Attention 5)

Yes, because the woman knows and feels more enjoyable and satisfying way to have her child. That when birth has no complications. (Attention 6)

Yes, women have every right by their decision regarding birth; they are the protagonist of the scene. Respect their opinion at the moment they are living and give all centered care to this decision. (Hosting 7) 


\section{Subcategory 3- Decision together}

In their speeches, the professionals demonstrate that women have the right to choose the type of birth. However, point out that this choice should be preceded by the guidance of a professional, especially if the advantages and disadvantages of each birth.

Yes, she has the right to choose what she thinks best, but it is good to remember that the opinions of experts during parturition is also of great importance, it makes a difference. (Caution 8)

Yes, but guided by the obstetrician with the basic notion for a good choice. (Hug 9)

Yes, if she is oriented about the birth to have more security. (Attention 30)

Yes, as long as the advantages and disadvantages of birth types were explained. (Companion 31)

Yes, it should be a decision together with the medical staff. (Hosting 16)

Yes, after clarification of the benefits and drawbacks of each type. (Care 17)

\section{Category 2 - Disagreement regarding the choice of birth type \\ Subcategory 1- Lack of Women}

This category shows that the professionals don't value knowledge of women in parturition, justifying that they wouldn't have a choice not to have knowledge.

No, we know that the best way is the vaginal and if it were to them, the patients choose, they certainly would choose the Cesarian. (Welcome 32)

No, because she does not know what the best type of birth is. (Companion 33)

No, she sometimes does not know what is best for her (not aware). (Hug 10)

I would not get the medical point of view to know the real information. (Affection 20)

No, because women who generally receive assistance do not have enough knowledge to choo- se, for they do not have opportunity. Given the experience I believe most would choose a surgical procedure (C-section). (Hosting 3)

No, because she do not always know what is best for her and her newborn. (Hug 11)

\section{Subcategory 2- Evaluation and medical advice}

Professionals delegate to medical birth choice, claiming that it is the professional who has the knowledge and criteria to choose what is best for mother and the baby.

No, because the professional (obstetrician) is the one who has the knowledge to know what is best for mother and baby. (Care 34)

It depends on medical evaluation. (Attention 23)

No, childbirth is an obstetric indication. (Care 21)

No, I would suggest not choose, as is medical criteria the best way with less risk for childbirth. (Companion 18)

No, it is for the doctor to evaluate the need. (Companion 35)

No, because vaginal parturition gives the woman a quick and free recovery risk for epidural anesthesia. If this is not possible, the doctor should be the one who decides by Caesarean section and not the patient, for her not want to feel pain. (Companion 36)

\section{Discussion}

The speeches of the professionals recognize the importance of women choose their type of childbirth, with prior guidelines on each type, valuing their choice and considering their emotions and feelings. What corresponds to that found in the literature, since the humanization of childbirth care includes respect for the professional to the parturient, using only care and necessary actions; the recognition of social and cultural aspects of parturition and birth; providing emotional support to women; providing 
autonomy and respecting the right of women to have a companion of their choice and be informed about all procedures to be undertaken [12-13].

The humanization of childbirth represents the appreciation of different subjects involved in the process of production of health, since the guidelines on pre-natal care, even the choice of procedures in childbirth, which implies convenient support, emotional and use of noninvasive methods and pharmacological not contributing to the well-being of the parturient woman [4]. The deployment of a humanized with excellence childbirth requires that the knowledge involved reassure and reflect on their practices and incorporate the public policies to strengthen the comprehensiveness of care [14].

The participants of the studies comprise that women have the right to choose their type of childbirth, by its role at that time and their autonomy in the choice. The definition of autonomy, according to the National Policy of Humanization means, "production of their own laws" or "right to be governed by their own laws. It means the whole system or body with the ability to build working rules for themselves and for the collective. Thinking individuals as autonomous subjects is to consider them as protagonists in the collectives that participate, jointly responsible for the production of self and the world in which they live [15].

However, the medical model-hegemonic, still very prevalent in birth rooms that impoverishes or even cancels the size of comprehensiveness of care, the woman is still seen as a mere object of subordination and not the protagonist of her story [16].

The need to recognize the individuality and humanize care means that the professional should establish with each woman a bond, realizing their needs and their ability to cope with the birth process [17].

With respect to joint decisions that involve the team and the user, the communication and information with the woman in labor, promotes autonomy, bringing benefit, there is an increasing involvement of women in their process of parturition [18-19].

In a study with puerperals there was mentioned guidelines for biomedical logic, which contributed to a failure in communication between health professionals and the mother during the period of pregnancy and puerperium, weakening the attention of caring, making it harder to form a bond that enhances the learning of women as the main protagonist of the process [20]. In this way, so that the bond is created, the care of patients by health professionals must be based on dialog, sensitivity, affection, in the pleasure of being with the other and the attention of the physical, mental, social and spiritual well-being. The establishment of a trust relationship with health professionals strengthens positive feelings that relax the parturient and acts as a genuine therapeutic relationship [21].

As a limiting to the woman choose her childbirth, the professionals believe that the lack of knowledge of the pregnant woman to disable to choose what is best for her and the baby. This is because the professional believes that has a set of knowledge: the technical knowledge and scientific applications. Its role is defined as a job, with rules and purposes equally well defined. Now the user arrives in a very diverse at this meeting. Is there any type of suffering or concern, any weakening that moves. In addition, he brings knowledge, but knowledge not specialized. However, these knowledge have the seal of experience, the experience more deeply what is the reason for the meeting with the professional and this must be valued by the professional, covering the biological and respecting the cultural, social, and emotional [13].

The preparation of the pregnant woman for childbirth includes the incorporation of a set of care, measures and activities that aim to offer the woman the opportunity to experience parturition and birth, as physiological processes, feeling the protagonist of the process.

Although reported that women have the right to choose their type of childbirth, professionals say 
that the choice depends on the medical decision. What toward the reality of maternity hospitals today, because with the evolution of parturition care, he became medicalized, hospital, technocratic assistance, influenced by the symbols of the enlightenment, associating the body as machine and the doctor as a mechanic. A woman has the right to make her own decisions in relation to the type of birth, without any coercion of a professional or even a team [13].

The violence of the imposition of routines that occur commonly in the vaginal as the position of parturition and the interference unnecessary obstetric, disrupt and inhibit the development of physiological mechanisms of childbirth, which becomes a synonym of pathology and medical intervention, transforming itself into an experience of terror, powerlessness, alienation and pain. In this way, it is not surprising that women believe that Cesarean is safer way to give birth, avoiding the pain and the traumatic experience [22]. Data from the Ministry of Health points the United States in 2010 as the world leader in C-sections [23].

Already in an international study, vaginal birth was considered the safest way and natural for a woman to have her son, for being the cesarean culturally condemned [24]. In a Brazilian study vaginal birth was the most chosen, contradicting the popularity of cesareans, because it is considered a physiological process [25].

The Ministry of Health has defined priority lines of care with the aim of improving the reality of maternal health, among the lines of care refers to qualify professionals for promotion of humanized and based on scientific evidence, with the creation of houses of the pregnant woman and the baby and Vaginal Delivery Centers, extra or intra-hospital. Fundamental initiative in changing the paradigm of care legislation, centered at the hospital and the care and medical technology, replacing with a model that values the social aspects of parturition and birth, without loss of safety, medical assistance [26].

\section{Conclusion}

Although the study participants report that the woman has the right to choose on her type of parturition, it was demonstrated with the statements of women are more exposed to the model of technocratic assistance, which reinforces the loss of their role in the process. In this way, actions of humanization should also take place during the academic formation in the courses involved, to build the idea of childbirth as a physiological moment, in which the care must stand out, and being not something pathological, but capable of treating or mechanisms of healing.

The battle for an assistance of quality during the perinatal period, with a focus on the empowerment of the mother, considering the individuals in all their complexity, continues and should be taken forward. It becomes necessary to have periodic evaluation of the centers involved, in order to evaluate the efficacy of actions in education and the continuing progression for a perinatal experience, ever better and more enjoyable.

\section{References}

1. Leão MRC, Riesco MLG, Schneck CA, Angelo M. Reflexões sobre o excesso de cesariana no Brasil e a autonomia das mulheres. Ciênc saúde coletiva 2013; 18(8): 2395-400.

2. Rebello MTMP, Rodrigues Neto JF. A humanização da assistência ao parto na percepção de estudantes de medicina. Rev bras educ méd 2012; 36(2): 188-97.

3. Brasil. Secretaria de Políticas de Saúde. Parto, aborto e puerpério: assistência humanizada à mulher. Brasília: Ministério da Saúde, 2001.

4. Fossa AM, Lino CM, Castilho RAM, Rocha MCP, Horibe TM. A experiência da enfermeira durante a assistência à gestante no parto humanizado. Saúde Rev 2015; 15(40): 25-36.

5. Diniz CSG, D'Orsi E, Domingues RMSM, Torres JA, Dias $M A B$, Schneck $C A$, et al. Implementation of the presence of companions during hospital admission for childbirth: data from the Birth in Brazil national survey. Cad saúde pública 2014; 30(suppl.1): 140-53.

6. Maia MB. Humanização do parto: política pública, comportamento organizacional e ethos profissional. Cad saúde pública 2011; 27(5): 1041-4. 
7. Martins CA, Almeida NAM, Mattos DV. Parto domiciliario planeado: asistido por enfermero obstetra. Enferm glob 2012; 11(3): 306-11.

8. Rattner D. Humanização na atenção a nascimentos e partos: ponderações sobre políticas públicas. Interface comun saúde educ 2009; 13(supl.1): 759-68

9. Rodrigues DP, Alves VH, Penna LHC, Branco MBLR, Souza RMP, SMM Padoin. Violence in obstetric care in the birth process: a descriptive exploratory study. Online braz j nurs (Online) [Internet] 2014 [cited 2016 Apr. 20]; 13(suppl I):399401. Available from: http://www.objnursing.uff.br/index.php/ nursing/article/view/4613

10. Aguiar MJ, Oliveira AFPL. Violência Institucional em Maternidades Públicas sob a ótica das usuárias. Interface - Comunic., Saude, Educ., São Paulo, 2010.

11. Bardin L. Análise de conteúdo. São Paulo: Edições 70, 2011.

12. Santos IS, Okazaki ELFJ. Assistência de enfermagem ao parto humanizado. Rev enferm Univ St Amaro 2012; 13(1): 64-8.

13. Silva ALS, Nascimento ER, Coelho EAC. Nurses practices to promote dignity, participation and empowerment of women in natural childbirth. Esc Anna Nery Rev Enferm 2015; 19(3): 42431.

14. Lucas MTB, Rocha MJF, Costa KMM, Oliveira GG, Melo JO. Nursing care during labor in a model maternity unit: crosssectional study. Online braz j nurs (Online) [Internet] 2015 [cited 2016 Apr. 20];14(1):32-40. Available from: http://www. objnursing.uff.br/index.php/nursing/article/view/5067/pdf 365

15. Brasil. Ministério da Saúde. HumanizaSUS: Documento base para gestores e trabalhadores do SUS. 4th ed. Brasília: Ministério da Saúde, 2010

16. Pinheiro BC, Bittar CML. Percepções, expectativas e conhecimentos sobre o parto normal: relatos de experiência de parturientes e dos profissionais de saúde. Aletheia 2012; 37 : 212-27.

17. Silva AP, Barros G, Colhaço VS, Santos EKA. As percepções das puérperas sobre traumas perineais decorrentes do parto normal. Revista Científica CENSUPEG 2013; 2: 54-74.

18. Frigo F, Basso RB, Erdtmann BK, Marin SM. A enfermagem e o cuidado humanístico na parturição. Rev Unincá 2013; 15(2): 0509.

19. Pimenta LF, Ressel LB, Santos CC, Wilhelm LA. The perceptions of women about the choice of delivery modes: adescriptive study. Online braz j nurs (Online) [Internet] 2013 [cited 2016 Apr 20]; 12(1): 135-44. Available from: http://www.objnursing.uff. br/index.php/nursing/article/view/3963/html

20. Cabral FB, Hirt LM, Van der Sand ICP. Prenatal care from puerperal women's point of view: frommedicalization to the fragmentation of care. Rev Esc Enferm USP [Internet] 2013[cited 2016 June 20]; 47(2): 281-7. Avaliable from: http://www.scielo. br/pdf/reeusp/v47n2/en 02.pdf
21. Pieszak GM, Terra MG, Neves ET, Pimenta LF, Padoin SMM, Ressel LB. Percepção dos profissionais de enfermagem acerca do cuidar em centro obstétrico. Rev Rene 2013; 14(3): 568-78.

22. Velho MB, Santos EKA, Briggemann AO, Camargo BV. Vivência do parto normal ou cesáreo: revisão integrativa sobre a percepção de mulheres. Texto \& contexto enferm 2012; 21(2): 458-66.

23. Gonçalves A, Silvestrin C. Análise de uma ação coletiva: comunicação e mobilização em defesa do direito de escolha da mulher em relação ao parto. Revista Lusófona de Estudos Culturais 2015; 3(1): 65-81.

24. Vásquez $C L$, Vanegas GS. Indagación desde los conocimientos, actitudes y prácticas en salud reproductiva femenina: algunos aportes desde la investigación. Enferm glob 2012; 11(2): 408-15.

25. Basso JF, Monticelli M. Expectations of Pregnant Women and Partners Concerning their Participation in Humanized Births. Rev latinoam enferm (Online) [Internet] 2010 [Cited 2016 June 30]; 18(3): 390-7. Avaliable from: http://www.scielo.br/pdf/rlae/ v18n3/14.pdf

26. Narchi NZ, Cruz EF, Gonçalves R. O papel das obstetrizes e enfermeiras obstetras na promoção da maternidade segura no Brasil. Ciênc saúde coletiva 2013; 18(4): 1059-68.

\section{Publish in International Archives of Medicine}

International Archives of Medicine is an open access journal publishing articles encompassing all aspects of medical science and clinical practice. IAM is considered a megajournal with independent sections on all areas of medicine. IAM is a really international journal with authors and board members from all around the world. The journal is widely indexed and classified Q1 in category Medicine. 